\title{
Study on the Assessment of Hepatotoxicity of Anti Hyperthyroid Drugs
}

\author{
Nimmy N John ${ }^{1 *}$, Narmadha MP ${ }^{1}$, Darath David ${ }^{1}$, H. Doddayya ${ }^{1}$
}

${ }^{1}$ N.E.T Pharmacy College, Raichur- 584103, Karnataka, India

\author{
DOI: $10.36348 /$ sjmps.2021.v07i03.003 \\ | Received: 24.02.2021 | Accepted: 08.03.2021 | Published: 30.03.2021 \\ *Corresponding author: Mrs. Nimmy N John
}

\section{Abstract}

In India, hyperthyroidism accounts for 5 per 10,000. The seriousness of thyroid disorders should not be underestimated as thyroid storm, thyrotoxicosis and myxedema coma can lead to death in a significant number of cases. In this study, 50 female patients of above 18-year-old were included in the study (Pre- and Post-menopausal), whereas patients who have undergone radioactive ablation and thyroidectomy were excluded. Blood samples were collected and thyroid tests like TSH, T3, T4 were performed by the method of chemiluminescence enzyme immunoassay. Complete Blood Count (CBC) is performed to check the values of $\mathrm{Hb}, \mathrm{RBC}, \mathrm{WBC}$, Neutrophil, Basophil, Eosinophil, Platelet, Lymphocyte. Liver function tests like SGOT and SGPT were performed to find whether carbimazole induces any liver damage. Thyroid tests and $\mathrm{CBC}$ values were noted down at the time of diagnosis and during the course of treatment. Out of 50 hyperthyroidism patients, 2 patients (\%) experienced Neutropenia and Agranulocytosis. According to a study done by Davies [6] Carbimazole shows rare adverse effects like neutropenia and agranulocytosis. In our study, 2 patients $(6.8 \%)$ experienced neutropenia and agranulocytosis. They have symptoms like blisters in mouth and fever. When their CBC were done, it was found that their neutrophil count and WBC has reduced. When neutrophil count is reduced, body's ability to fight off foreign body reduces and it ensures easy attack by micro-organism.

Key words: Thyroxin, Neutropenia, Agranulocytosis, Hyperthyroidism.

Copyright () 2021 The Author(s): This is an open-access article distributed under the terms of the Creative Commons Attribution 4.0 International License (CC BY-NC 4.0) which permits unrestricted use, distribution, and reproduction in any medium for non-commercial use provided the original author and source are credited.

\section{INTRODUCTION}

Hyperthyroidism is the term for overactive tissue within the thyroid gland that causes an overproduction of thyroid hormones. The prevalence and pattern of Thyroid disorders depends on sex, Age, ethnic and geographical factors and especially on iodine intake. High intake of iodine is associated with a higher prevalence of hyperthyroidism. In India, grave's disease accounts 5 per 10,000 [4]. The seriousness of thyroid disorders should not be underestimated as thyroid storm, thyrotoxicosis, and myxedema coma can lead to death in a significant number of cases according to recent studies.

Antithyroid drugs prescribed are Propylthiouracil (PTU), Carbimazole, and Methimazole \& Radioactive iodine. PTU was considered as the first choice of drug for the treatment of hyperthyroidism and thyrotoxicosis. But studies have shown that the liver toxicity and increased plasma cholesterol level occurs due to the drug [4]. Rivkees et al. bring to fore front an issue that the use of PTU can result in tragic consequences and should never be used in children and in early pregnancy [1]. PTU is identified as third most frequent cause of drug induced liver transplantation. Methimazole can also induce liver toxicity but these effects are milder and confined to cholestasis not associated with liver failure and more frequent in people older than 60 years of age [3]. Also, FDA reported that PTU leads to serious liver damage. Since radioactive iodine can lead to hypothyroidism, it is also not considered as a drug of choice. At present, the best drug for hyperthyroidism is Carbimazole. But the suspected adverse effects of carbimazole are liver toxicity and neutropenia. So, the present study was aimed to assess the effect of carbimazole on liver and on blood counts.

\section{Material ANd Methods}

The proposed protocol was approved and accepted by Institutional Ethics Committee. It was prospective parallel study conducted at a tertiary care hospital in Calicut, Kerala from July 2019 to March 2020. Fifty female patients of above 18-year-old were included in the study (Pre- and Post-menopausal), whereas patients who have undergone radioactive ablation and thyroidectomy were excluded from the study. Patients underwent the tests for thyroid hormone 
and blood count. Blood samples were collected and thyroid tests like TSH, T3, T4 were performed by the method of chemiluminescence enzyme immunoassay. Complete blood count is performed to check $\mathrm{Hb}, \mathrm{RBC}$, WBC, Neutrophil, Basophil, Eosinophil, Platelet, and Lymphocyte. Liver function tests like SGOT and SGPT were performed to find whether carbimazole induces any liver damage. Thyroid tests and CBC values were noted down at the time of diagnosis and during the course of treatment. In hyperthyroidism patients, mean TSH value was $0.16533 \mathrm{~m} \mathrm{IU/ml} \mathrm{before} \mathrm{commencing}$ treatment and it has increased to $1.3216 \mathrm{~m} \mathrm{IU} / \mathrm{ml}$ by the end of treatment. Significant decrease in mean T3 value and T4 value were observed with 6 months of treatment.

\section{RESULTS}

Prevalence of hyperthyroidism is more in the age of $>55$ years. In his studies, Franklyn found out the highest number of hyperthyroid patients were in the age group 55-65years and hypothyroid patients in the age group 30-40 years [2]. In our study the prevalence is found to be $60 \%$ in patients of $>55$ years.

Thyroid tests like TSH, T3, and T4 were checked before initiating the treatment. Effect of carbimazole on liver was tested by performing SGOT and SGPT test. TSH test is the most sensitive test for detecting the hyperthyroid state because the hypothalamic-Pituitary axis compensates very quickly for even slight increase in circulating free hormone T3, T4 by releasing less TSH. TSH level is decreased in hyperthyroidism and increased in hypothyroidism [3]. (Table 1)

Before the initiation of treatment mean TSH of patients was $0.16533 \mathrm{mIU} / \mathrm{ml}$. After one month of treatment, it has increased to $0.84 \mathrm{mIU} / \mathrm{ml}$ and in 3 months mean TSH increased to $1.32 \mathrm{mIU} / \mathrm{ml}$.

Serum T3 provides direct reflection of thyroid function indicating hormone availability to tissues. In hyperthyroidism patients, mean T3 value before commencing treatment was $128.5 \mathrm{ng} / \mathrm{ml}$. But in duration of one month, T3 has decreased to 98.43 $\mathrm{ng} / \mathrm{ml}$. And in three months mean value has come to $79.19 \mathrm{ng} / \mathrm{ml}$. A $25 \%$ result is obtained within 3 months of treatment.

Serum T4 level gives a direct image of any abnormality in thyroid gland. High T4 value is the indication of hyperthyroidism. In hyperthyroidism patients, mean T4 value before commencing treatment was $21.403 \mathrm{ng} / \mathrm{ml}$. But in a duration of one month, T4 has decreased to $18.8 \mathrm{ng} / \mathrm{ml}$. And in the duration of three months mean value has come to $10.1 \mathrm{ng} / \mathrm{ml}$. Since it's a long-term treatment, achieving the normal range with in duration of 3 months is not possible. But considerable change is observed in the hormone level.

Out of 50 hyperthyroidism patients, 2 patients $(6.8 \%)$ experienced neutropenia and agranulocytosis. Carbimazole shows rare adverse effects like neutropenia and agranulocytosis. In our study, 2 patients $(6.8 \%)$ experienced neutropenia and agranulocytosis. They got the symptoms like blisters in mouth and fever. When their CBC were done, it was found that their neutrophil count and $\mathrm{WBC}$ has reduced. When neutrophil count is reduced, body's ability to fight off reduces and it ensures easy bacterial attack.

Out of 50 hyperthyroidism patients, all of them have normal level of hepatic enzymes.

Skin rashes were found in one patient which has not been reported so far as carbimazole's adverse effect.

Carbimazole was suspected to have hepatotoxicity according to Kapil [14]. So hepatic enzymes were checked in our patients using the biomarkers SGOT and SGPT. But none of their hepatic enzymes has deviated from normal value. So Carbimazole does not induce hepatotoxicity.

Table-1: Impact of Carbimazole on Thyroid hormones (TSH, T3, T4)

\begin{tabular}{|l|l|l|l|}
\hline & $\begin{array}{l}\text { TSH mean } \pm \text { SD }(\text { SEM }) \\
(\mathbf{m I U} / \mathbf{m l})\end{array}$ & $\begin{array}{l}\text { T3 mean } \pm \text { SD }(\text { SEM }) \\
(\mathbf{n g} / \mathbf{d} \text { L) }\end{array}$ & $\begin{array}{l}\text { T4 mean } \pm \text { SD }(\text { SEM }) \\
(\mathbf{n g} / \mathbf{d ~ L )}\end{array}$ \\
\hline Before treatment & $0.16533 \pm 0.0596(0.01089)$ & $128.5 \pm 9.194(1.679)$ & $21.403 \pm 4.679(0.8543)$ \\
\hline After 1 month of treatment & $0.75 \pm 0.0588(0.0123)$ & $110.78 \pm 9.89(0.6676)$ & $17.89 \pm 8.96(0.0675)$ \\
\hline $\begin{array}{l}\text { After 3 months } \\
\text { of treatment }\end{array}$ & $1.3216 \pm 0.502(0.09173)$ & $98.43 \pm 8.951(1.634)$ & $10.1 \pm 1.789(0.3251)$ \\
\hline
\end{tabular}


Table-2: Impact of carbimazole on hepatic enzymes and CBC

\begin{tabular}{|c|c|c|c|c|}
\hline Tests & Before treatment & $\begin{array}{l}\text { After } 1 \text { month of } \\
\text { treatment }\end{array}$ & $\begin{array}{l}\text { After } 3 \text { months of } \\
\text { treatment }\end{array}$ & $\begin{array}{l}\text { After } 6 \text { months of } \\
\text { treatment }\end{array}$ \\
\hline SGOT & $33 \mathrm{U} / \mathrm{L}$ & $31 \mathrm{U} / \mathrm{L}$ & $33 \mathrm{U} / \mathrm{L}$ & $35 \mathrm{U} / \mathrm{L}$ \\
\hline SGPT & $38 \mathrm{U} / \mathrm{L}$ & $42 \mathrm{U} / \mathrm{L}$ & $44 \mathrm{U} / \mathrm{L}$ & $37 \mathrm{U} / \mathrm{L}$ \\
\hline $\mathrm{Hb}$ & $14 \mathrm{~g} / \mathrm{dL}$ & $13 \mathrm{~g} / \mathrm{dL}$ & $12 \mathrm{~g} / \mathrm{dL}$ & $13 \mathrm{~g} / \mathrm{dL}$ \\
\hline $\mathrm{RBC}$ & 5.7million/UL & 5.4million/UL & 5.5million/UL & 5.4million/UL \\
\hline WBC & $11.8 \times 10^{9} / \mathrm{L}$ & $11.3 \times 10^{9} / \mathrm{L}$ & $9.8 \times 10^{9} / \mathrm{L}$ & $8.8 \times 10^{9} / \mathrm{L}$ \\
\hline Neutrophil & $3.5 \times 10^{9} / \mathrm{L}$ & $3.5 \times 10^{9} / \mathrm{L}$ & $2 \times 10^{9} / \mathrm{L}$ & $2 \times 10^{9} / \mathrm{L}$ \\
\hline Eosinophil & $3 \%$ & $2 \%$ & $4 \%$ & $3 \%$ \\
\hline Platelets & 2 lakhs & 2.5 lakhs & 3 lakhs & 2.8 lakhs \\
\hline Basophil & $0 \%$ & $0 \%$ & $0 \%$ & $0 \%$ \\
\hline
\end{tabular}

\section{CONCLUSION}

The complications associated with hyperthyroidism are severe osteoporosis, atrial fibrillation, Grave's ophthalmopathy, Grave's dermopathy and ultimately to thyrotoxic crisis. Studies have shown that anti-hyperthyroid drugs like PTU, Methimazole is associated with liver toxicity but these effects are confined to cholestasis, not associated with liver failure and more frequent in people older than 60 years of age [3]. Carbimazole was suspected to have hepatotoxicity according to Davies [6]. So hepatic enzymes were checked in our patients using the biomarkers SGOT and SGPT. But none of their hepatic enzymes has deviated from normal value. So Carbimazole does no induce hepatotoxicity.

\section{ACKNOWLEDGMENTS}

Authors take it as a privilege to acknowledge E.M.S Memorial Hospital, Calicut, Medical Director, Endocrinology Department E.M.S Memorial Hospital, and Calicut. HOD of Swamy Vivekananda College of Pharmacy, Erode. Principal; N.E.T Pharmacy College, HODs of department of Pharmacy practice and Medicine department and the staffs for their support during the study. Special thanks to Dr. Narmadha MP, for her valuable guidance and suggestions throughout our project work.

\section{REFERENCE}

1. Rivkees, S. A., \& Szarfman, A. (2010). Dissimilar hepatotoxicity profiles of propylthiouracil and methimazole in children. The Journal of Clinical Endocrinology \& Metabolism, 95(7), 3260-3267.

2. Barbero, P., Valdez, R., Rodríguez, H., Tiscornia, C., Mansilla, E., Allons, A., \& Liascovich, R. (2008). Choanal atresia associated with maternal hyperthyroidism treated with methimazole: a casecontrol study. American Journal of Medical Genetics Part A, 146(18), 2390-2395.

3. Russo, M. W., Galanko, J. A., Shrestha, R., Fried, M. W., \& Watkins, P. (2004). Liver transplantation for acute liver failure from drug induced liver injury in the United States. Liver Transplantation, 10(8), 1018-1023.

4. Rahway, N., Merck, U. (1992). Hypothyroidism The Merck manual of diagnosis and Therapy, 45(8); 933-938.

5. Dunn, J.T., Hixson, J. (2002). Thyroid function and prevalence of antithyroperoxidase Antibodies in United States population. J Clin Endocrinol Metab, 87; 489-99.

6. Davies, M.R. (1998). John Factors affecting thyroidism in Americans. Indian Journal of Medical physiology, 42(2), 58-62.

7. Davies, M.R. (1998). John Factors affecting thyroidism in Americans. Indian Journal of Medical physiology, 42(2), 58-62.

8. Weetman, A. P., Ratanachaiyavong, S., Middleton, G. W., Love, W., John, R., Owen, G. M., \& McGregor, A. M. (1986). Prediction of outcome in Graves' disease after carbimazole treatment. QJM: An International Journal of Medicine, 59(1), 409419.

9. Metso, S., Jaatinen, P., Huhtala, H., Luukkaala, T., Oksala, H., \& Salmi, J. (2004). Long- term follow- up study of radioiodine treatment of hyperthyroidism. Clinical endocrinology, 61(5), 641-648.

10. Franklyn, J.A., Masonneuve, P. (1998). Antonelli Mortality after the treatment of hyperthyroidism with radioactive iodine. The New England journal of medicine; 338:712-718. 